\title{
Subjective Well-Being Bagi Istri Nelayan di Desa Gisik Cemandi Sidoarjo
}

\author{
Resa Ayu Firdiati ${ }^{1}$ \\ Fakultas Psikologi, Program Studi Psikologi, Universitas Hang Tuah Surabaya \\ resaayu0898@gmail.com \\ Rini Nurahaju ${ }^{2}$ \\ Fakultas Psikologi, Program Studi Psikologi, Universitas Hang Tuah Surabaya \\ rini-n11@paska.unair.ac.id
}

\begin{abstract}
Generally, the income of the coastal community is not sufficient to meet their daily needs. The socio-economic status or welfare of the fishing community has not changed much, as in Gisik Cemandi Village. The fishermen and their wives work to make ends meet. The purpose of this study was to determine how the subjective well-being of fishermen's wives with these conditions. This type of qualitative research used in this research is a case study with a descriptive method. The technique of extracting data used interviews with two fishermen's wives. The results showed that subject one was more dominant in the affective aspect while subject two was more dominant in the cognitive aspect of living his life. They are actually both grateful for the situation they are experiencing, but there are differences in emotional control factors
\end{abstract}

Keywords: Fisherman's Wife. Gisik Cemandi Village, Subjective Well-Being

\begin{abstract}
Abstrak
Pendapatan masyarakat pesisir umumnya tidak cukup memenuhi kebutuhan seharihari. Status sosial ekonomi atau kesejahteraan masyarakat nelayan pun belum banyak berubah, seperti di Desa Gisik Cemandi. Para nelayan dan istri bekerja untuk memenuhi kebutuhannya. Tujuan penelitian ini adalah untuk mengetahui bagaimana subjective well-being para istri nelayan dengan kondisi tersebut. Tipe penelitian kualitatif yang digunakan dalam penelitian ini adalah studi kasus dengan metode deskriptif. Teknik penggalian data menggunakan wawancara terhadap dua orang istri nelayan. Hasil penelitian menunjukkan bahwa subjek satu lebih dominan pada aspek afektif sedangkan subjek dua lebih dominan pada aspek kognitif dalam menjalani hidupnya. Mereka sebetulnya sama-sama mensyukuri pada situasi kondisi yang dialami, namun ada perbedaan pada faktor pengontrolan emosi
\end{abstract}

Kata kunci: Desa Gisik Cemandi, Istri Nelayan, Subjective Well-Being 


\section{PENDAHULUAN}

Wilayah pesisir adalah daerah pertemuan antara darat dan laut, ke arah darat wilayah pesisir meliputi bagian daratan, baik kering maupun terendam air, yang masih dipengaruhi sifat-sifat laut seperti pasang surut, angin laut dan perembesan air asin. Sedangkan ke arah laut, wilayah pesisir mencakup bagian laut yang masih dipengaruhi oleh proses-proses alami yang terjadi di darat seperti sedimentasi dan aliran air tawar maupun yang disebabkan oleh kegiatan manusia di darat seperti penggundulan hutan dan pencemaran (Carlos, 2011).

Menurut data dari Departemen Kelautan dan Perikanan, setiap tahun sektor perikanan mampu meningkatkan sumbangannya terhadap pendapatan Negara bukan pajak. Namun ironisnya adalah masyarakat nelayannya merupakan golongan masyarakat paling miskin di Asia bahkan dunia. Pengamatan langsung kedesa-desa nelayan dapat memberikan gambaran yang jauh lebih jelas tentang kemiskinan nelayan di tengah kekayaan. Pemandangan yang sering dijumpai di desa nelayan adalah lingkungan hidup yang kumuh dan rumah-rumah yang sangat sederhana (Mulyadi, 2005).

Masyarakat yang tinggal di daerah pantai saat ini mendapat perhatian tersendiri dari pemerintah dengan harapan agar kesejahteraan dapat ditingkatkan. Secara relative, pendapatan masyarakat nelayan umumnya tidak cukup memenuhi kebutuhan sehari-hari. Status sosial ekonomi atau kesejahteraan masyarakat nelayan pun belum banyak berubah (Yuswar, 2007).

Rumah tangga nelayan sudah lama diketahui tergolong miskin, selain rumah tangga petani sempit, buruh tani, dan pengrajin. Istri nelayan ternyata memiliki peranan yang penting dalam mengatasi kemiskinan yang dialaminya. Dalam mengatur rumah tangga nelayan, sangat memungkinkan pentingnya peran iastri terutama dalam pengelolaan keuangan rumah tangga. Istri nelayan memiliki peran ganda yaitu sebagai pencari nafkah ketika pendapatan suami tidak cukup untuk mencukupi kebutuhan rumah tangga mereka (Anggita, 2012), memiliki peran penting dalam peningkatan pendapatan rumah tangga (Handayani \& Artini, 2009) yang menyatakan bahwa perempuan bekerja adalah untuk membantu ekonomi keluarga.

Demikian pula yang terjadi pada masyarakat di daerah Sidoarjo tepatnya di desa Gisik Cemandi. Setiap hari para istri nelayan antara lain memiliki kegiatan mengupas kulit kerang dan itu dilakukan setelah mereka menjalankan tugasnya yaitu memasak untuk keluarganya. Mereka mendapatkan kulit kerang dari juragan atau yang biasa disebut dengan bos yang ada di daerah itu. Upah yang didapatkan dari jumlah kilogram kupasan kulit kerang yang dihasilkan tidak begitu tinggi. Terkadang setiap harinya mendapatkan upah Rp 10.000. Hanya berapa ribu 
perkilonya tetapi observasi penulis, para wanita tersebut menjalankan tugasnya tanpa mengeluh walaupun pekerjaan yang mereka lakukan tidak sebanding dengan upah yang didapat. Mereka tidak mempunyai pilihan lain karena tidak mempunyai keterampilan lainnya. Penulis tergelitik dengan apa yang ada dalam pikiran para istri nelayan mengenai kehidupannya. Apakah mereka merasa puas, ataukah mempunyai perasaan negatif?

Diener dan Lucas (dalam Oktrina, 2015) mengatakan bahwa evaluasi seseorang tentang kehidupannya, termasuk evaluasi kognitif terhadap kepuasan hidupnya serta evaluasi afektif (suasana hati dan cemas) seperti perasaan emosional yang positif dan negatif dinamakan subjective well-being. Individu dikatakan memiliki subjective well-being rendah jika tidak puas dengan kehidupannya, mengalami sedikit kegembiraan dan afeksi, serta lebih sering merasakan emosi negatif seperti kemarahan atau kecemasan. Sedangkan individu yang dicirikan dengan tingginya tingkat kepuasan terhadap hidup serta tingginya tingkat emosi positif dan rendahnya tingkat emosi negatif dikatakan memiliki subjective well-being tinggi.

Menurut Diener (2009) subjective well-being terbagi menjadi dua komponen utama, yaitu Komponen Kognitif (Kepuasan Hidup) dan Komponen Afektif (Perasaan Senang). Komponen Kognitif merupakan kesenjangan yang dipersepsikan antara keinginan dan pencapaiannya apakah terpenuhi atau tidak. Kepuasan hidup (life satisfaction) merupakan penilaian kognitif seseorang mengenai kehidupannya, apakah kehidupan yang dijalaninya berjalan dengan baik. Ini merupakan perasaan cukup, damai, dan puas dari kesenjangan antara keinginan dan kebutuhan dengan pencapaian dan pemenuhan. Komponen Afektif (Perasaan Senang) termasuk mood dan emosi yang menyenangkan dan tidak menyenangkan. Orang bereaksi dengan emosi yang menyenangkan ketika mereka menganggap sesuatu yang baik terjadi pada diri mereka, dan bereaksi dengan emosi yang tidak menyenangkan ketika menganggap sesuatu yang buruk terjadi pada mereka, karenanya mood dan emosi bukan hanya menyenangkan dan tidak menyenangkan tetapi juga mengindikasikan apakah kejadian itu diharapkan atau tidak. Afeksi negatif merepresentasikan mood dan emosi yang tidak menyenangkan, dan merefleksikan respon negatif yang dialami seseorang sebagai reaksinya terhadap kehidupan, kesehatan, keadaan, dan peristiwa yang mereka alami.

Hasil penelitian Krause (2006) menunjukkan bahwa orang-orang yang bersyukur kepada Tuhan memiliki lebih sedikit emosi negatif dalam hidupnya. Rasa kebersyukuran dapat membantu seseorang dalam mengatasi peristiwa kehidupan yang sulit, sehingga meningkatkan subjective well-being seseorang dalam jangka panjang (Wood, Joseph \& Linley, 2007). 
Penelitian yang dilakukan oleh Meina (2011) pada pedagang pasar tradisional Pulogadung menunjukkan bahwa bersyukur tidak secara signifikan berhubungan dengan kebahagiaan, karena kebahagiaan tidak hanya ditentukan oleh bersyukur saja, namun oleh berbagai macam faktor yaitu gender, usia, pendidikan, tingkat pendapatan, pernikahan, dan pekerjaan.

Berdasarkan penelitian yang dilakukan sebelumnya oleh (Maulana, Firdaus, 2013) berjudul "Peran Istri Nelayan dalam Meningkatkan Pendapatan Rumah Tangga" mengungkapkan dimana ketika pendapatan kepala keluarga meningkat maka kecenderungan pendapatan pada istri nelayan juga meningkat. Selain itu pada penelitian kedua oleh Olii dan Baruadi (2015) berjudul "Studi Peran Perempuan Pesisir dalam Menunjang Aktivitas Perikanan di Desa Torosiage" mengungkapkan bagaimana faktor pendukung peningkatan peran perempuan adalah kemampuan kerjanya tinggi, dorongan keluarga cukup kuat, dan lokasi kegiatan merupakan objek wisata potensial yang membutuhkan aktivitas perempuan dalam perdagangan. Kendala yang dihadapi adalah rendahnya akses perempuan terhadap sumber daya modal, transportasi dan informasi.

Penelitian yang dilakukan oleh (Iin Siti, Nayu, 2017) berjudul "Peran Produktif Wanita Pesisir dalam Menunjang Usaha Perikanan di Kecamatan Tempuran" mengungkapkan bahwa, sebanyak 75\% dari wanita pesisir berpendidikan Sekolah Dasar. Aktivitas wanita pesisir mayoritas $(71,9 \%)$ sebagai buruh pengolahan hasil perikanan baik produk ikan asin dan atau terasi. Sebanyak $25 \%$ wanita pesisir beraktivitas sebagai pedagang hasil perikanan (ikan segar, ikan asin, dan terasi); sejumlah 3,1\% merupakan buruh pengolahan dan pedagang hasil perikanan.

Penelitian ini adalah membahas tentang subjective well-being para istri nelayan yang ada di desa Gisik Cemandi Sidoarjo. Walaupun para suami tidak bisa mendapatkan hasil yang sesuai dengan apa yang diinginkan oleh istrinya, apakah para istri tetap bisa merasakan kebahagiaan ditengah keterbatasan ekonomi.

\section{METODE}

Jenis penelitian kualitatif yang digunakan dalam penelitian ini adalah studi kasus dengan metode deskriptif. Subjek penelitian adalah dua istri nelayan Desa Gisik Cemandi Sedati, Sidoarjo. Proses penelitian, penulis mencari responden yang sesuai dengan kriteria dimana istri nelayan tersebut memang bekerja untuk membantu kebutuhan keluarganya yaitu 
antara lain mengupas kulit kerang. Awalnya bertemu dengan ibu ketua RT, namun karena tidak bisa memahami bahasa Indonesia, diarahkan pada putrinya yang juga seorang istri nelayan (subjek 1). Sedangkan subjek 2 didapatkan dengan cara diperkenalkan oleh ibu ketua RT pada temannya. Setelah penulis mendapatkan subjek, barulah mereka diberi beberapa pertanyaan sesuai dengan panduan wawancara. Panduan wawancara mencakup komponen afektif dan komponen kognitif.

Peneliti melakukan penggalian data secara langsung dimana penulis mendatangi rumah subjek. Wawancara dilakukan selama dua kali pada masing-masing subjek. Wawancara 1 dan ke-2 dilakukan pada tanggal 18 Mei 2020 dan 20 Mei 2020.Tahapan analisis data mengacu pada Miles dan Huberman (1992) yakni (1) pengumpulan data, (2) reduksi data, (3) penyajian data, dan (4) penarikan kesimpulan.

\section{HASIL DAN PEMBAHASAN}

Karakteristik subjek penelitian yang didapatkan adalah seperti yang ditunjukkan pada tabel 1 :

Tabel 1

Karakteristik Subjek Penelitian

\begin{tabular}{llll}
\hline No & Karakteristik & Subjek 1 & Subjek 2 \\
\hline 1. & Nama & SA & TN \\
\hline 2. & Usia & 38 tahun & 47 tahun \\
\hline 3. & Lokasi & 1.Ruang tamu & 1.Dapur \\
& Wawancara & 2.Ruang tamu & 2.Belakang rumah \\
\hline 4. & Pekerjaan & Pengupas kulit kerang & Pengupas kulit kerang \\
\hline
\end{tabular}

Hasil perbandingan wawancara kedua subjek dapat dirangkum sebagai berikut.

Tabel 2

Hasil Wawancara Aspek Subjective Well-Being Istri Nelayan

\begin{tabular}{llll}
\hline No. & Aspek & Subjek 1 & Subjek 2 \\
\hline 1. & Kognitif & - Berpikir bahwa jika ia sakit, susah & - Berpikir keadaan keluarga sampai \\
& & untuk bekerja membantu ekonomi & kapan begini terus \\
& & keluarga & - Kondisi saat ini yang berdampak \\
& & - Keadaan pandemi membuat ia & pada penghasilan \\
& & selalu berpikir tentang nasib & - Memikirkan supaya anaknya pintar \\
& keluarganya & dalam sekolahnya hingga sukses \\
& & nantinya \\
& semua yang terjadi cepat berlalu & \\
& & & \\
\hline 2. & Afektif & - Selalu bersyukur & - Senang dapat membantu suami \\
& & & - Mensyukuri kondisi apapun \\
\hline
\end{tabular}


- Merasa senang karena masih bisa bantu suami

- Merasa emosi (marah) jika suami pulang melaut tidak membawa hasil seperti yang diharapkan.

- Kondisi tersebut membuat subjek menjadi sedih bahkan sakit.
- Marah jika suami tidak membawa hasil tapi berpikir untuk apa marah karena tidak ada gunanya.

- Merasa masih bias tertawa setelah marah.

- Merasa senang karena masih bisa berkumpul bersama keluarga

Dari wawancara selama dua hari yang penulis lakukan, didapatkan hasil bahwa hanya berapa ribu perkilo dari hasil mengupas kulit kerang tetapi subjek penelitian menjalankan tugasnya dengan sepenuh hati, tanpa mengeluh walaupun pekerjaan yang mereka lakukan tidak sebanding dengan upah yang didapat. Walau pekerjaan tersebut terkesan berat tetapi mereka senang karena menambah penghasilan untuk makan sehari-hari. Mereka tidak mempunyai keterampilan lain selain mengupas kulit kerang. Ketika para subjek penelitian ini ditanya keinginan untuk kedepannya, ada subjek yang menjawab tidak tahu dan ada juga yang berharap agar hidup mereka bisa lebih baik lagi.

Hasil wawancara juga menunjukkan perasaan subjek. Subjek 1 merasa sedih. Dalam wawancara kedua ia menjawab pertanyaan sambil menangis. Hatinya lebih mudah tersentuh. Emosinya lebih sering berubah-ubah. Ketika suami pulang tidak mendapatkan hasil seperti yang diinginkannya, ia merasa emosi atau marah. Ia berpikir bahwa betapa susahnya keadaan saat ini belum lagi karena adanya pandemi. Upah yang ia dapatkan untuk membantu memenuhi kebutuhan keluarga jadi lebih sedikit. Selain itu ia juga memikirkan bagaimana keadaan anaknya jika harus di rumah terus, akan jadi seperti apa anaknya kelak.

Untuk subjek 2 ia lebih dominan menggunakan kognitifnya dalam menjalani hidup. Ia selalu berpikir tentang keadaan ekonominya apalagi upah yang didapatkan menurun pada saat pandemi. Namun subjek 2 ini masih bisa mengontrol emosinya dalam menyikapi keadaan. Ia lebih bisa memaknai arti kebahagiaan dengan lebih bersyukur, tidak mudah terpancing emosi, tidak mudah marah. Walaupun marah ia bisa kembali melupakan masalah tersebut dan bisa lebih berfikir kalau memang sudah jalannya seperti itu.

Disini bisa dilihat subjective well-being subjek penelitian bervariasi. Ada yang lebih dominan menggunakan kognitifnya dan ada juga yang afektifnya lebih tinggi.

Penelitian ini memiliki keterbatasan yakni belum sepenuhnya menggali informasi secara mendalam tentang subjective well-being istri nelayan karena belum mewawancarai keluarga subjek terutama suami sebagai informan penelitian. 


\section{SIMPULAN}

Berdasarkan hasil penelitian yang dilakukan kepada subjek dapat disimpulkan bahwa subjek 1 lebih dominan pada aspek afektif sedangkan subjek 2 lebih dominan pada aspek kognitif dalam menjalani hidupnya. Mereka sebetulnya sama-sama mensyukuri pada situasi kondisi yang dialami, namun ada perbedaan pada faktor pengontrolan emosi. Saran yang dapat diberikan untuk peneliti selanjutnya yaitu mendalami fenomena subjective well-being istri nelayan dengan teknik penggalian data yang lebih optimal..

\section{DAFTAR PUSTAKA}

Aryanti, T. F. (2019). Hubungan antara kebersyukuran dengan subjective well-being pada nelayan di Tegal [Skripsi, Universitas Kristen Satya Wacana]. Perpustakaan Universitas Kristen Satya Wacana.

Djunaidah. I. S., \& Nurmalia, N. (2018). Peran produktif wanita pesisir dalam menunjang usaha perikanan di Kecamatan Tempuran Kabupaten Karawang. J.Sosek KP, 13(2), 229-237

Firdaus, M., \& Rahadian, R. (2015). Peran istri nelayan dalam meningkatkan pendapatan rumah tangga. Jurnal Sosek KP, 10 (1), 241-249.

Harahap, A., Fauzia, L., \& Emalisa. (2012). Peranan istri nelayan terhadap pendapatan keluarga [Tesis, Universitas Trunojoyo Madura]. Magister Manajemen Sumber Daya Pantai. Universitas Trunojoyo Madura.

Kusuma, E. (2019). Sumber makna hidup nelayan pantai menganti: Studi Interpretative Phenomenological Approach (IPA). Psychosophia: Journal of Psychology, Religion, and Humanity, 1(1), 62-81.

Sumrin, Olii, A. H., \& Baruadi, A. S. R.(2015). Studi peran perempuan pesisir dalam menunjang aktivitas perikanan di Desa Torosiaje Laut Kecamatan Popayato Kabupaten Pohuwato. Nike: Jurnal Ilmiah Perikanan dan Kelautan, 3(1), 16-19.

Susilowati, S. P. (2006). Peran Istri Nelayan Dalam Meningkatkan Kesejahteraan Rumah Tangga [Skripsi, Universitas Negeri Semarang]. Perpustakaan Universitas Negeri Semarang. 